\title{
Mechanical Properties and Corrosion Characteristics of Thermally Aged Alloy 22
}

\author{
R.B. Rebak, P. Crook
}

This article was submitted to 2002 American Society of Mechanical Engineers Pressure Vessels and Piping Conference, Vancouver, Canada, August 4-8, 2002

\section{May 30, 2002}

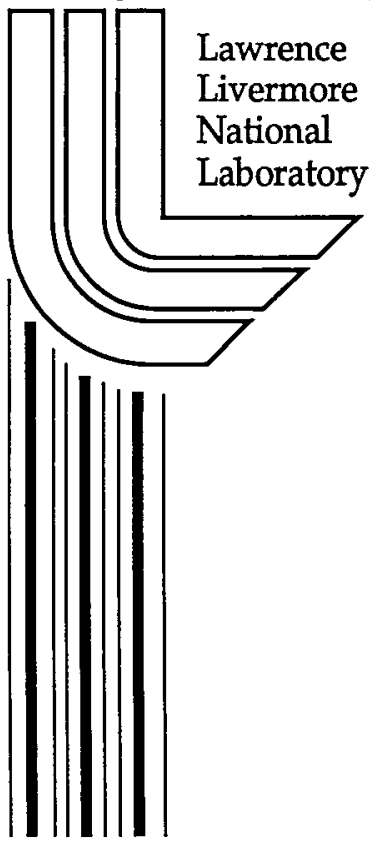




\section{DISCLAIMER}

This document was prepared as an account of work sponsored by an agency of the United States Government. Neither the United States Government nor the University of California nor any of their employees, makes any warranty, express or implied, or assumes any legal liability or responsibility for the accuracy, completeness, or usefulness of any information, apparatus, product, or process disclosed, or represents that its use would not infringe privately owned rights. Reference herein to any specific commercial product, process, or service by trade name, trademark, manufacturer, or otherwise, does not necessarily constitute or imply its endorsement, recommendation, or favoring by the United States Government or the University of California. The views and opinions of authors expressed herein do not necessarily state or reflect those of the United States Government or the University of California, and shall not be used for advertising or product endorsement purposes.

This is a preprint of a paper intended for publication in a journal or proceedings. Since changes may be made before publication, this preprint is made available with the understanding that it will not be cited or reproduced without the permission of the author.

This report has been reproduced directly from the best available copy.

Available electronically at http://www.doc.gov/bridge

Available for a processing fee to U.S. Department of Energy

And its contractors in paper from

U.S. Department of Energy

Office of Scientific and Technical Information

P.O. Box 62

Oak Ridge, TN 37831-0062

Telephone: (865) 576-8401

Facsimile: (865) 576-5728

E-mail: reports@adonis.osti.gov

Available for the sale to the public from

U.S. Department of Commerce

National Technical Information Service

5285 Port Royal Road

Springfield, VA 22161

Telephone: (800) 553-6847

Facsimile: (703) 605-6900

E-mail: orders@ntis.fedworld.gov

Online ordering: http://www.ntis.gov/ordering.htm

OR

Lawrence Livermore National Laboratory

Technical Information Department's Digital Library

http://www.llnl.gov/tid/Library.html 


\title{
MECHANICAL PROPERTIES AND CORROSION CHARACTERISTICS \\ OF THERMALLY AGED ALLOY 22
}

\author{
Raúl B. Rebak \\ Lawrence Livermore National Laboratory, Livermore, CA, USA \\ Paul Crook \\ Haynes International Inc., Kokomo, IN, USA
}

\begin{abstract}
Alloy 22 (UNS N06022) is a candidate material for the external wall of the high level nuclear waste containers for the potential repository site at Yucca Mountain. In the mill-annealed (MA) condition, Alloy 22 is a single face centered cubic phase. When exposed to temperatures on the order of $600^{\circ} \mathrm{C}$ and above for times higher than $1 \mathrm{~h}$, this alloy may develop secondary phases that reduce its mechanical toughness and corrosion resistance. The objective of this work was to age Alloy 22 at temperatures between $482^{\circ} \mathrm{C}$ and $760^{\circ} \mathrm{C}$ for times between $0.25 \mathrm{~h}$ and $6,000 \mathrm{~h}$ and to study the mechanical and corrosion performance of the resulting material. Aging was carried out using wrought specimens as well as gas tungsten arc welded (GTAW) specimens. Mechanical and corrosion testing was carried out using ASTM standards. Results show that the higher the aging temperature and the longer the aging time, the lower the impact toughness of the aged material and the lower its corrosion resistance. However, extrapolating both mechanical and corrosion laboratory data predicts that Alloy 22 will remain corrosion resistant and mechanically robust for the projected lifetime of the waste container.
\end{abstract}

Keywords: nuclear waste container, N06022, aging, mechanical properties, corrosion resistance.

\section{INTRODUCTION}

Alloy 22 (UNS N06022) is a nickel-based alloy, which contains approximately $22 \%$ chromium (Cr), $13 \%$ molybdenum (Mo), $3 \%$ tungsten (W) and $3 \%$ iron ( $\mathrm{Fe}$ ). Alloy 22 has excellent resistance to pitting corrosion, crevice corrosion and stress corrosion cracking in halide containing environments. ${ }^{1-11}$ Consequently, Alloy 22 is a candidate material to fabricate the external layer of the high level nuclear waste containers for the potential repository site in Yucca Mountain, Nevada. ${ }^{12-13}$

Due to the heat generated by the radioactive decay of the waste, the containers might experience temperatures as high as $160^{\circ} \mathrm{C}$ during their first 1000 years of emplacement. The lifetime design of the containers is 10,000 years. Previous studies have shown that the mechanical and corrosion properties of Alloy 22 did not change when it was aged for up to $40,000 \mathrm{~h}$ at $427^{\circ} \mathrm{C} .{ }^{4,6} \mathrm{However}$, it is known that precipitation of detrimental second phases occurs when Alloy 22 is aged at temperatures above $600^{\circ} \mathrm{C} .^{13-19}$ The precipitation of these secondary phases that are formed at temperatures approximately $600^{\circ} \mathrm{C}$ and higher affect the corrosion resistance in aggressive acidic solutions and the mechanical properties of wrought and welded Alloy $22 .{ }^{13-24}$ 
The purpose of this work was to study the effect of aging time and aging temperature on the mechanical properties and corrosion behavior of Alloy 22 both wrought and welded.

\section{EXPERIMENTAL TECHNIQUE}

Aging studies and posterior mechanical and corrosion testing were carried out using wrought and welded Alloy 22 (N06022). (1) Wrought Material: For mechanical properties or Charpy impact test the samples were machined from 0.5 -inch $(12.7 \mathrm{~mm})$ thick plate. The testing conditions of the notched samples were according to ASTM E $23 .^{25}$ Most of these tests were carried out using Heat 2277-6-3171 (Table 1). Samples were aged for times between 0.5 and $6,000 \mathrm{~h}$ at $593^{\circ} \mathrm{C}, 649^{\circ} \mathrm{C}, 704^{\circ} \mathrm{C}$ and $760^{\circ} \mathrm{C}$. For the aging times of 2,000 and 16,000 h Heats 2277-3-3223 and 2277-0-3195 were used. Heat 2277-7-3173 was used for the aging temperatures of $260^{\circ} \mathrm{C}, 343^{\circ} \mathrm{C}$ and $427^{\circ} \mathrm{C} .{ }^{6}$ For the Charpy impact energy testing, the samples were aged in air using an approximate shape and later machined to the final testing shape after aging. For the corrosion studies, the coupons were prepared from 0.25 -inch $(\sim 6 \mathrm{~mm})$ thick plate Heat 2277-6-3181 (Table 1) for the temperature range between $482^{\circ} \mathrm{C}$ and $760^{\circ} \mathrm{C}$ and from 0.5 -inch thick plate of Heat $2277-7-3173$ for the temperature range between $260^{\circ} \mathrm{C}$ and $427^{\circ} \mathrm{C} .^{6}$ (2) Welded Material: For the mechanical properties, coupons were prepared from 0.5 -inch thick plate. The base metal was Heat 2277-9-3201 and the weld wire was from Heat 2277-8-3281 (Table 1). Gas Tungsten Arc Welding (GTAW) was carried in an argon atmosphere. The weld seam consisted on a single $V$ and contained 9 passes. For the corrosion studies of welded material, two 0.125-inch $(-3 \mathrm{~mm})$ thick sheets of Alloy 22 Heat 2277-9-3237 (Table 1) were welded using Alloy 22 filler metal wire 0.125-inch diameter Heat 2277-8-3277 (Table 1). After welding the plates were sliced in strips approximately 0.5-inch wide. Each strip contained a weld seam in the center. The samples were aged for $0.25 \mathrm{~h}, 0.5 \mathrm{~h}, 1 \mathrm{~h}, 3 \mathrm{~h}, 6 \mathrm{~h}, 10 \mathrm{~h}, 30$ $\mathrm{h}, 60 \mathrm{~h}, 100 \mathrm{~h}, 300 \mathrm{~h}, 600 \mathrm{~h}, 1000 \mathrm{~h}, 3,000 \mathrm{~h}$ and $6,000 \mathrm{~h}$ at $900^{\circ} \mathrm{F}\left(482^{\circ} \mathrm{C}\right), 1000^{\circ} \mathrm{F}\left(538^{\circ} \mathrm{C}\right), 1100^{\circ} \mathrm{F}$ $\left(593^{\circ} \mathrm{C}\right), 1200^{\circ} \mathrm{F}\left(649^{\circ} \mathrm{C}\right), 1300^{\circ} \mathrm{F}\left(704^{\circ} \mathrm{C}\right)$ and $1400^{\circ} \mathrm{F}\left(760^{\circ} \mathrm{C}\right)$. Aging was performed in air, and afterwards, the samples were rapid air-cooled. The coupons for immersion testing contained by length approximately $1 / 3$ of weld material and $2 / 3$ of base material (1/3 at each side of the weld). Before testing the samples were cleaned by vapor blasting. Changes in the corrosion resistance were measured using standard immersion tests such as a boiling aqueous solution of $50 \%$ sulfuric acid $\left(\mathrm{H}_{2} \mathrm{SO}_{4}\right)+42 \mathrm{~g} / \mathrm{l}$ of ferric sulfate $\left(\mathrm{Fe}_{2}\left(\mathrm{SO}_{4}\right)_{3}\right)$ and boiling $2.5 \%$ hydrochloric acid $(\mathrm{HCl})$. The first test solution is also called the Streicher test or ASTM G $28 \mathrm{~A}^{25}$ This electrolyte boils at $120^{\circ} \mathrm{C}$ and is highly oxidizing. The second test solution is highly reducing, was carried out according to ASTM G 31 and it boils at approximately $101^{\circ} \mathrm{C}^{25}$ The ASTM G $28 \mathrm{~A}$ test was carried out for $24 \mathrm{~h}$ and the boiling $\mathrm{HCl}$ test was carried out for a total time of $96 \mathrm{~h}$ (the electrolyte solution was changed every $24 \mathrm{~h}$ ). In these two tests, the solutions were open to the atmosphere through a condenser and a scrubber. Since the solutions were boiling, it is assumed that the amount of dissolved oxygen was insignificant.

\section{RESULTS AND DISCUSSION}

Mechanical Testing (Impact Energy)

The Charpy or impact energy test measures the toughness of a material. That is, the higher the impact (Charpy) energy, the higher both the strength and the elongation of the material before rupture. Alloy 22 in the mill-annealed condition absorbs the maximum energy of $264 \mathrm{ft} . \mathrm{lb}$ ( 358 Joule) from the Charpy testing pendulum and does not break, only bends. However, if this alloy is aged at high temperatures, its 
mechanical toughness decreases. Figure 1 shows the impact energy for Alloy 22 as a function of aging temperature and aging time. The toughness for the MA wrought material was approximately $264 \mathrm{ft.lb}$ and an aging time of approximately $10 \mathrm{~h}$ is required at $760^{\circ} \mathrm{C}$ for Alloy 22 to start its mechanical degradation. The lower the temperature, the higher this threshold time. For aging temperatures of $427^{\circ} \mathrm{C}$ and below, aging times as high as $40,000 \mathrm{~h}$ did not cause a change in the impact energy. ${ }^{6}$ Figure 2 shows a similar graph for the impact energy as a function of aging temperature and aging time for GTAW Alloy 22 coupons. For the as-welded coupons, the impact energy was approximately $160 \mathrm{ft} . \mathrm{lb}$, that is, the impact toughness of a GTAW microstructure was approximately $60 \%$ of the impact toughness of a wrought structure (Figure 1). Figure 2 shows that GTAW Alloy 22 also suffered higher toughness loss for higher aging temperatures and longer aging times. Moreover, for the welded coupons (Figure 2), the degradation of the mechanical properties at each temperature seemed to start at lower threshold times than for wrought coupons (Figure 1). It was shown before that the impact energy loss by the aged material correlated well with the amount of tetrahedrally close packed (PCP) phases present in the aged microstructure. ${ }^{21}$ Figure 3 shows the time that is needed at each aging temperature for the aged microstructure (wrought and GTAW) to reach a toughness of approximately $60 \%$ of the un-aged value. That is, Figure 3 shows the time needed for the aged coupons to reach a toughness of $150 \mathrm{ft} . l \mathrm{~b}$ for the wrought microstructure (Figure 1) and $100 \mathrm{ft.lb}$ for the GTAW microstructure (Figure 2). Figure 3 shows that, even though, a GTAW microstructure suffered toughness loss at shorter time than the wrought microstructure, the degradation rate of both microstructures was the same. If the slopes of both curves in Figure 3 are equated to $-Q_{a p} / R, Q_{a p}$ is the apparent activation energy for the aging process in Alloy 22 and $R$ is the gas constant. Calculations show that this apparent activation energy, as determined by Charpy impact energy mechanical testing, was $228 \mathrm{~kJ} / \mathrm{mol}$ for wrought material and $235 \mathrm{~kJ} / \mathrm{mol}$ for GTAW material. Figure 3 also shows that both wrought and welded Alloy 22 will retain at least $60 \%$ of its initial toughness value even if aged at $350^{\circ} \mathrm{C}$ for times as long as 10,000 years.

\section{Immersion Corrosion Testing}

Figures 4 and 5 show the corrosion rate of wrought and GTAW Alloy 22 in ASTM G 28A solution for seven aging temperatures and thirteen different aging times, respectively. The corrosion rate of aged Alloy 22 in this oxidizing solution (G 28A) increased gradually as the aging time and the aging temperature increased (for $\mathrm{T} \geq 538^{\circ} \mathrm{C}$ ). For samples aged at $482^{\circ} \mathrm{C}$ the corrosion rate remained the same, even after aging for $10,000 \mathrm{~h}$ (Figure 4). Observation of the tested coupons in the ASTM G 28 A solution showed preferential corrosion at the grain boundaries. At higher aging times deeper grain boundary attack was observed, and in certain testing conditions some grains fell away because they became completely detached from the samples.

Figures 6 and 7 show the corrosion rate of wrought and GTAW Alloy 22 in boiling $2.5 \% \mathrm{HCl}$ solution, respectively. For both types of coupons, the corrosion rate increased approximately three times after a certain threshold aging time at each temperature. The higher the temperature the lower the threshold time. Figure 6 shows that for the wrought coupons, the corrosion rate decreased slightly with the aging time. This behavior seems to suggest that a small amount of aging would be beneficial for corrosion resistance. For the higher aging temperatures $\left(760,704\right.$ and $\left.649^{\circ} \mathrm{C}\right)$, the corrosion rate seemed to reach a plateau for an intermediate aging time. This behavior is more noticeable for the GTAW coupons (Figure 7). For both types of samples aged at $482^{\circ} \mathrm{C}$ the corrosion rate remained the same, even after aging for $3,000 \mathrm{~h}$. Observation of the tested coupons in boiling $2.5 \% \mathrm{HCl}$ solution showed preferential intergranular attack which became deeper and wider as the aging time increased. At aging times of $1000 \mathrm{~h}$ and higher, preferential corrosion attack at twins inside the grains was observed. 
Figures 8 and 9 show the effect of welding on the corrosion rate of Alloy 22. Most of the corrosion rates of wrought Alloy 22 were published before. ${ }^{13,21,22}$ Figure 8 shows the corrosion rate in ASTM G 28 A for wrought and as-welded coupons at two aging temperatures $\left(760^{\circ} \mathrm{C}\right.$ and $\left.538^{\circ} \mathrm{C}\right)$ as a function of aging time. For all aging times, the corrosion rate of welded coupons was always higher than the corrosion rate of wrought coupons. For example, at the aging temperature of $760^{\circ} \mathrm{C}$ and at the aging time of $10 \mathrm{~h}$, the corrosion rate of the welded coupons was approximately two times the corrosion rate of the wrought coupons. Figure 9 shows the corrosion rate in boiling $2.5 \% \mathrm{HCl}$ solution for wrought and as-welded coupons at two aging temperatures $\left(760^{\circ} \mathrm{C}\right.$ and $538^{\circ} \mathrm{C}$ ) as a function of aging time. For all aging times, the corrosion rate of welded coupons was always higher than the corrosion rate of wrought coupons. For the shorter aging times (up to 3-6 h) the corrosion rate of the welded coupons was approximately three times the corrosion rate of the wrought coupons; however, for aging times of $6 \mathrm{~h}$ and longer, the difference in the corrosion rate was smaller.

Figure 10 shows the time necessary at each aging temperature for Alloy 22 to reach a corrosion rate of $80 \mathrm{mpy}$ ( $\sim 2 \mathrm{~mm} / \mathrm{year}$ ) in ASTM G $28 \mathrm{~A}$, both for. wrought and welded materials (from Figures 4 and 5 ). Figure 10 shows that at each aging temperature, a shorter aging time is required for the welded material to reach the threshold corrosion rate of $80 \mathrm{mpy}$. This threshold value is generally the maximum allowed value for in-plant quality control. Figure 10 shows that the Arrhenius slopes for both materials are the same, that is, the degradation of the welded material started earlier than the degradation for the wrought material; however, the degradation rate was the same. If the slopes of both curves in Figure 10 are equated to $-Q_{a p} / R, Q_{2 p}$ is the apparent activation energy for the aging process in Alloy 22 and $R$ is the gas constant. Calculations show that this apparent activation energy, as determined by corrosion testing in oxidizing conditions (ASTM G $28 \mathrm{~A}$ ) was $261 \mathrm{~kJ} / \mathrm{mol}$ for wrought material and $262 \mathrm{~kJ} / \mathrm{mol}$ for GTAW material. A similar plot for corrosion in boiling $2.5 \% \mathrm{HCl}$ (reducing conditions) showed $\mathrm{Q}_{\mathrm{ap}}=$ $244 \mathrm{~kJ} / \mathrm{mol}$ for wrought material and $\mathrm{Q}_{\mathrm{ap}}=306 \mathrm{~kJ} / \mathrm{mol}$ for GTAW material. For the $2.5 \% \mathrm{HCl}$ solution, the curves for both materials were not parallel as in the case of the ASTM G 28 A solution (Figure 10). Assuming that the aging mechanism remains the same at the lower temperatures, Figure 10 shows that if the Arrhenius relationship is extrapolated to aging temperatures of $300^{\circ} \mathrm{C}$, aging times higher than 10,000 years would be necessary for Alloy 22 to show a degradation corresponding to a corrosion rate of 80 mpy.

\section{CONCLUSIONS}

(1) The impact energy (toughness) of Alloy 22 in the MA wrought condition was $264 \mathrm{ft} .1 \mathrm{~b}$ and of the GTAW condition was $160 \mathrm{ft} . \mathrm{lb}$.

(2) Aging at temperatures in the range $593^{\circ} \mathrm{C}$ to $760^{\circ} \mathrm{C}$ caused a decrease in the toughness of both wrought and GTAW Alloy 22. The higher the aging temperature and the higher the aging time the larger the toughness loss.

(3) Extrapolating mechanical toughness laboratory data suggest that Alloy 22 will retain at least $60 \%$ of its toughness even after aging it for 10,000 years at $350^{\circ} \mathrm{C}$.

(4) When wrought and welded Alloy 22 coupons were aged at temperatures between $538^{\circ} \mathrm{C}$ and $760^{\circ} \mathrm{C}$, the corrosion rate in oxidizing (ASTM G $28 \mathrm{~A}$ ) and reducing (boiling $2.5 \% \mathrm{HCl}$ ) solu- 
tions increased both with the aging temperature and aging time.

(5) For the same aging temperature and aging time, the corrosion rate of GTAW Alloy 22 was higher than the corrosion rate of wrought material.

(6) The corrosion degradation rate of Alloy 22 due to high temperature aging was the same for wrought and GTAW materials.

\section{ACKNOWLEDGMENTS}

The authors appreciate the outstanding laboratory work of Michael Newburn, Jim Barnes, Tina Corbin, Bill Rubush, Rupinder Sharma, Mark Britton, Jeffrey Dillman, Natalie Koon and Joe Gibson at Haynes International Inc. Part of this work was performed under the auspices of the U. S. Department of Energy by University of California Lawrence Livermore National Laboratory under contract $N^{\circ}$ W-7405-Eng48. This work is supported in part by Yucca Mountain Site Characterization Project.

\section{DISCLAIMER}

This document was prepared as an account of work sponsored by an agency of the United States Government. Neither the United States Government nor the University of California nor any of their employees, makes any warranty, express or implied, or assumes any legal liability or responsibility for the accuracy, completeness, or usefulness of any information, apparatus, product, or process disclosed, or represents that its use would not infringe privately owned rights. Reference herein to any specific commercial product, process, or service by trade name, trademark, manufacturer, or otherwise, does not necessarily constitute or imply its endorsement, recommendation, or favoring by the United States Government or the University of California. The views and opinions of authors expressed herein do not necessarily state or reflect those of the United States Government or the University of California, and shall not be used for advertising or product endorsement purposes.

\section{REFERENCES}

1. P. E. Manning, J. D. Schöbel, Werkstoffe und Korrosion, 37, (1986): p 137.

2. A. I. Asphahani, The Arabian Journal for Science and Engineering, Volume 14, Number 2, (1989): p. 317.

3. S. J. Lukezich, The Corrosion Behavior of Ni-Base High Performance Alloys in Simulated Repository Environments, MS Thesis, The Ohio State University, 1989.

4. R. B. Rebak, in Proceedings of the Symposium on Passivity and Its Breakdown, Volume 97-26 (Pennington, NJ: The Electrochemical Society, 1998): p. 1001

5. A. K. Roy, D. L. Fleming, B. Y. Lum, MP, March, (1998): p. 54.

6. R. B. Rebak and N. E. Koon, Corrosion/98, Paper 153, (Houston, TX: NACE International, 1998).

7. K. A. Gruss, G. A. Cragnolino, D. S. Dunn, N. Sridhar, Corrosion/98, Paper 149 (Houston, TX: NACE International, 1998). 
8. R. B. Rebak, P. Crook, in Critical Factors in Localized Corrosion III, Volume PV 98-17 (Pennington, NJ: The Electrochemical Society, 1999): p. 289.

9. R. B. Rebak, N. E. Koon, J. P. Cotner, P. Crook, in Passivity and Localized Corrosion, Volume PV 99-27 (Pennington, NJ: The Electrochemical Society, 1999): p. 473

10. D. S. Dunn, G. A. Cragnolino, N Sridhar, in Scientific Basis for Nuclear Waste Management XXII, Vol. 556 (Warrendale, PA: Materials Research Society, 1999): p. 879.

11. B. A. Kehler, G. O. Ilevbare, J. R. Scully, Corrosion/2000, Paper 182 (Houston, TX: NACE International, 2000).

12. D. S. Dunn, G. A. Cragnolino, N Sridhar, in Scientific Basis for Nuclear Waste Management XXIII, Vol. 608 (Warrendale, PA: Materials Research Society, 2000): p. 89.

13. R. B. Rebak, N. E. Koon, J. R. Dillman, P. Crook, T. S. Edgecumbe Summers, Corrosion/2000, Paper 181 (Houston, TX: NACE International, 2000).

14. S. J. Matthews in Proceedings of the Third International Conference on Superalloys, (Baton Rouge, LA: Claitor's Publishing Division, 1976): p. 215.

15. U. L. Heubner, E. Altpeter, M. B. Rockel and E. Wallis, Corrosion, 45 (1989): p. 249.

16. H. M. Tawancy, J. Mater. Sci., 31 (1996): p. 3929.

17. T. S. Edgecumbe Summers, M. A. Wall, M. Kumar, S. J. Matthews, R. B. Rebak, in Scientific Basis for Nuclear Waste Management XXII, Vol. 556 (Warrendale, PA: Materials Research Society, 1999): p. 919.

18. R. B. Rebak, N. E. Koon, P. Crook, in Electrochemical Approach to Selected Corrosion and Corrosion Control Studies, Number 28 (London, UK: The Institute of Materials, 2000): p. 245

19. R. B. Rebak, T. S. Edgecumbe Summers, R. M. Carranza, in Scientific Basis for Nuclear Waste Management XXIII, Vol. 608 (Warrendale, PA: Materials Research Society, 2000): p. 109.

20. T. S. Edgecumbe Summers, T. Shen, R. B. Rebak in Ageing Studies and Lifetime Extension of Materials, (New York, NY: Kluwer Academic/Plenum Publisher, 2001): p. 507

21. T. S. Edgecumbe Summers, R. B. Rebak, T. A. Palmer and P. Crook in Scientific Basis for Nuclear Waste Management XXV (To be published by the Materials Research Society).

22. R. B. Rebak, T. S. Edgecumbe Summers, T. Lian, R. M. Carranza, J. R. Dillman, T. Corbin and P. Crook, Corrosion/2002, Paper 542 (Houston, TX: NACE International, 2002).

23. D. S. Dunn and C. S. Brossia, Corrosion/2002, Paper 548 (Houston, TX: NACE International, 2002).

24. P. Lin, G. Palumbo, D. Limoges, D. Lee and M. MacKenzie, Corrosion/2002, Paper 547 (Houston, TX: NACE International, 2002).

25. Annual Book of ASTM Standards, Volumes 03.01 (E 23) and 03.02 (G 28A, G 31) (West Conshohocken, PA: American Society for Testing and Materials, 2001). 
TABLE 1

CHEMICAL COMPOSITION OF SOME STUDIED ALLOY 22 HEATS (WT\%)

\begin{tabular}{lccccc}
\hline Element & $2277-6-$ & $2277-8-$ & $2277-6-$ & $2277-9-$ & $2277-8-$ \\
& 3181 & 3281 & 3171 & 3237 & 3277 \\
\hline $\mathrm{C}$ & 0.004 & 0.006 & 0.002 & 0.0047 & 0.0066 \\
$\mathrm{Co}$ & 1.11 & 1.10 & 0.70 & 0.9 & 1.1 \\
$\mathrm{Cr}$ & 21.59 & 21.58 & 21.97 & 21.26 & 21.58 \\
$\mathrm{Fe}$ & 3.9 & 4.17 & 4.42 & 3.97 & 4.17 \\
$\mathrm{Mn}$ & 0.28 & 0.25 & 0.23 & 0.25 & 0.25 \\
$\mathrm{Mo}$ & 13.64 & 13.29 & 13.31 & 13.15 & 13.29 \\
$\mathrm{Ni}$ & $\sim 56.3$ & $\sim 55.5$ & $\sim 56.25$ & -57.4 & -56.3 \\
$\mathrm{P}$ & 0.013 & $\mathrm{NA}$ & $\mathrm{NA}$ & 0.01 & 0.005 \\
$\mathrm{~S}$ & 0.001 & $\mathrm{NA}$ & $\mathrm{NA}$ & 0.003 & 0.0031 \\
$\mathrm{~V}$ & 0.17 & 0.18 & 0.15 & 0.21 & 0.18 \\
$\mathrm{~W}$ & 3.03 & 3.18 & 2.86 & 2.90 & 3.18 \\
\hline
\end{tabular}

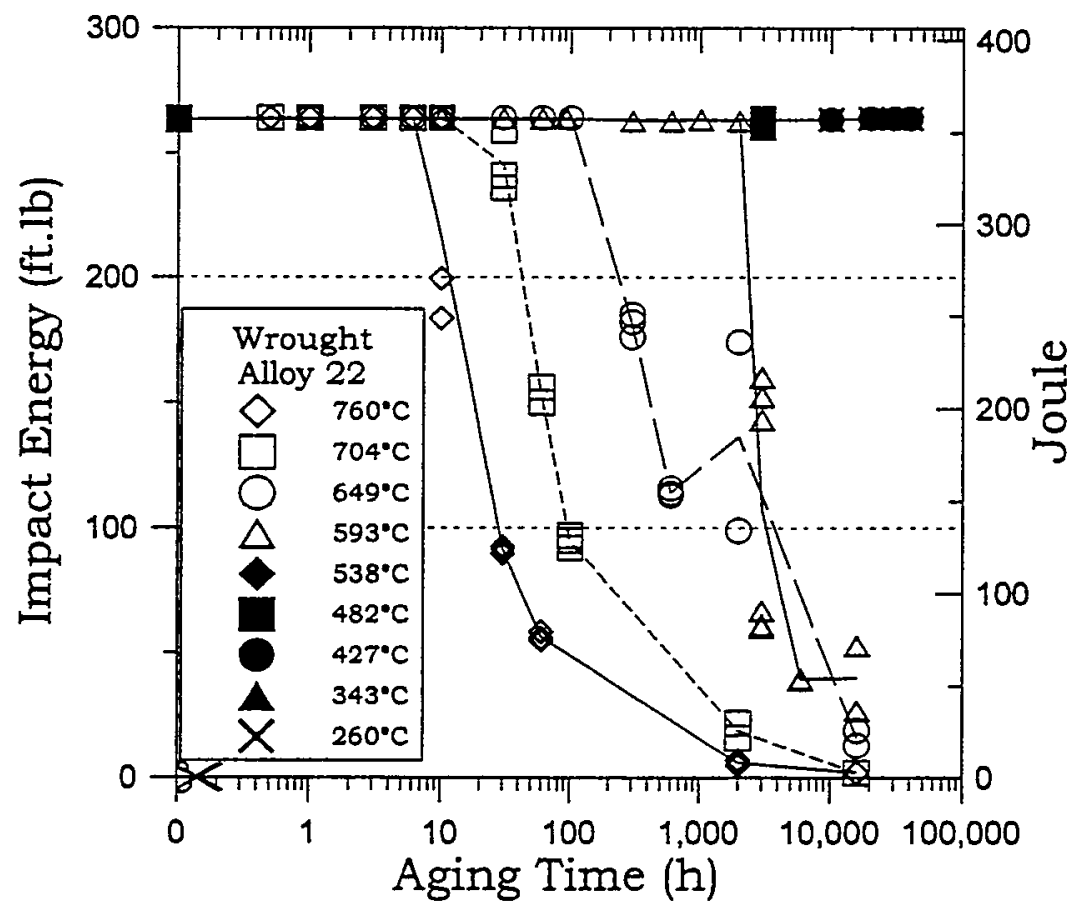

FIGURE 1: Impact energy for wrought Alloy 22 as a function of aging temperature and aging time. 


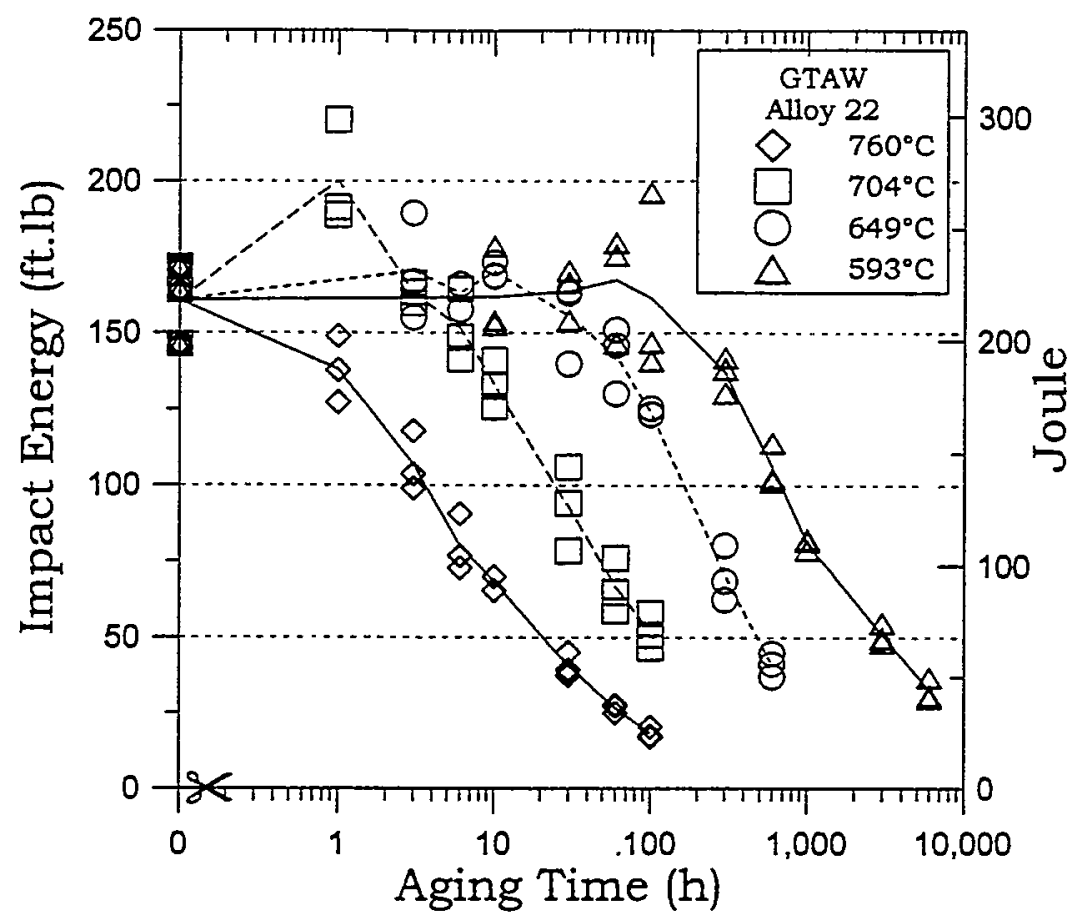

FIGURE 2: Impact energy for GTAW Alloy 22 as a function of aging temperature and aging time.

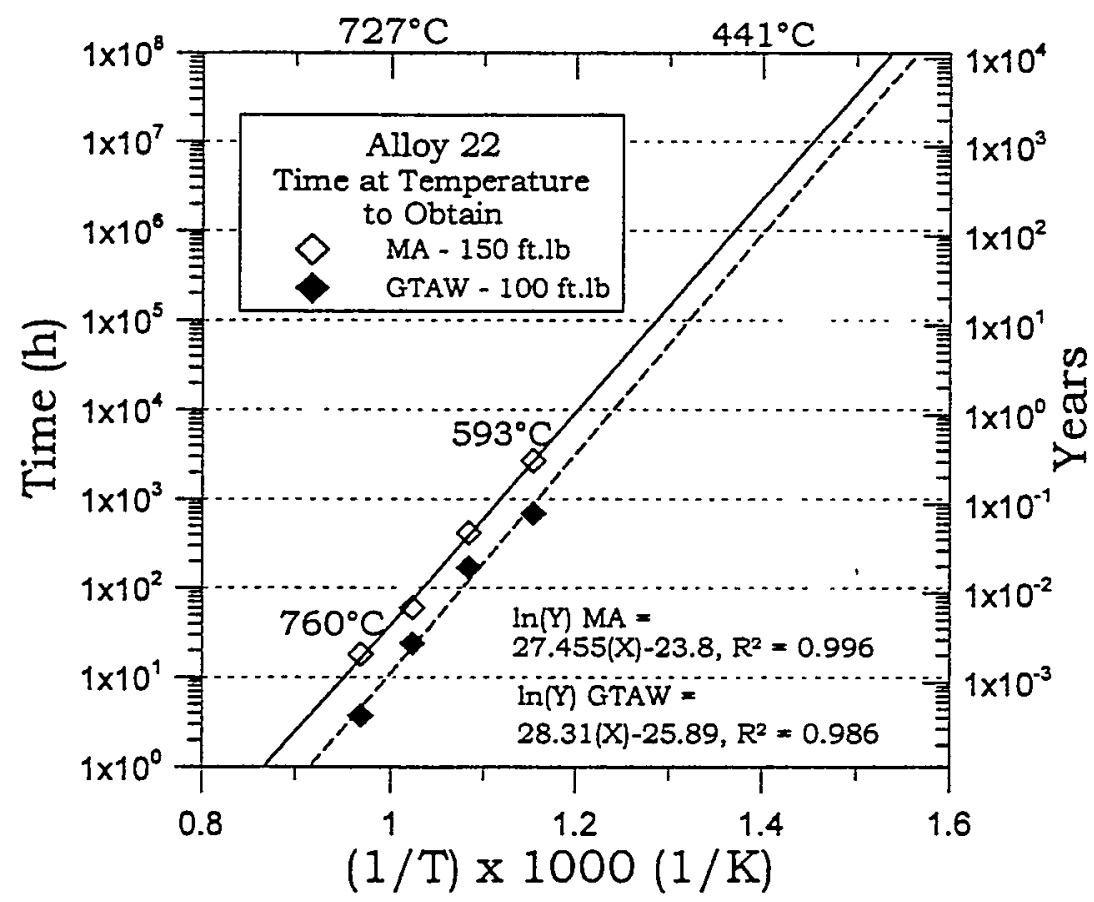

FIGURE 3: Arrhenius extrapolation based in the time needed at each temperature to reach an impact energy approximately $60 \%$ of its initial value. 


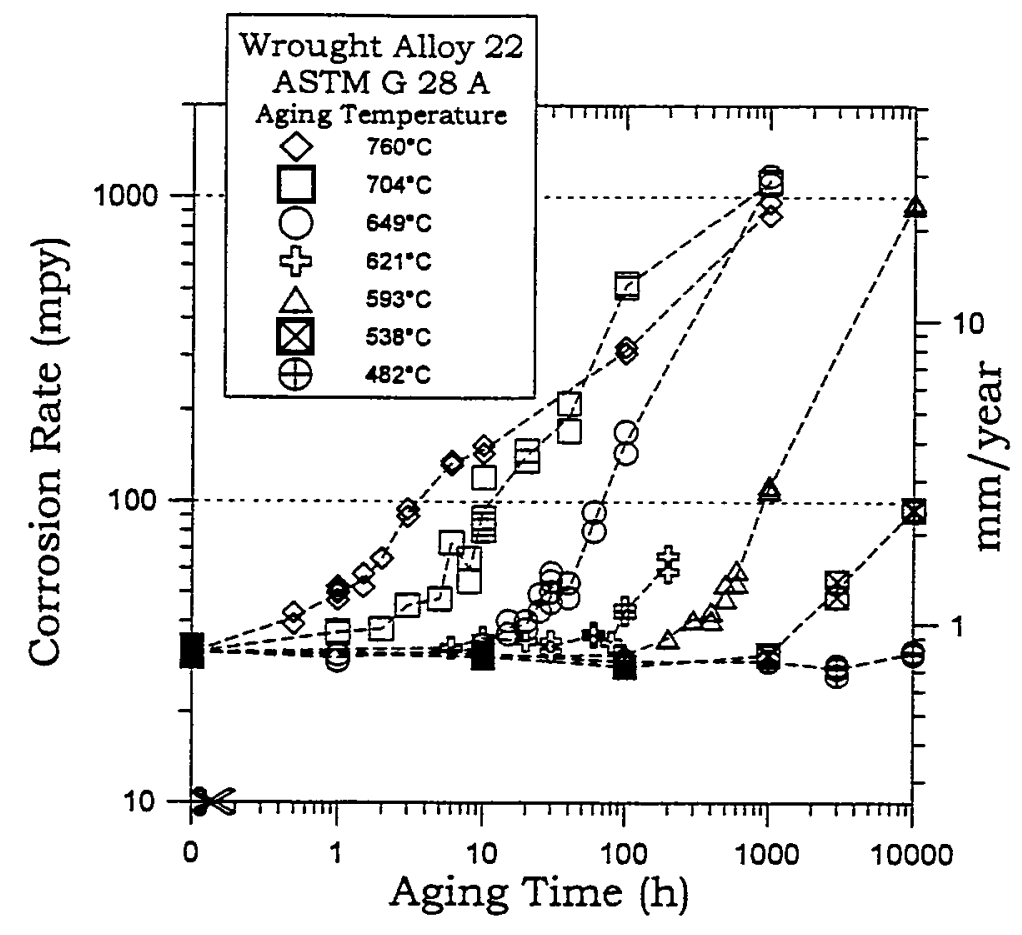

FIGURE 4: Corrosion rate of aged wrought Alloy 22 in ASTM G 28 A.

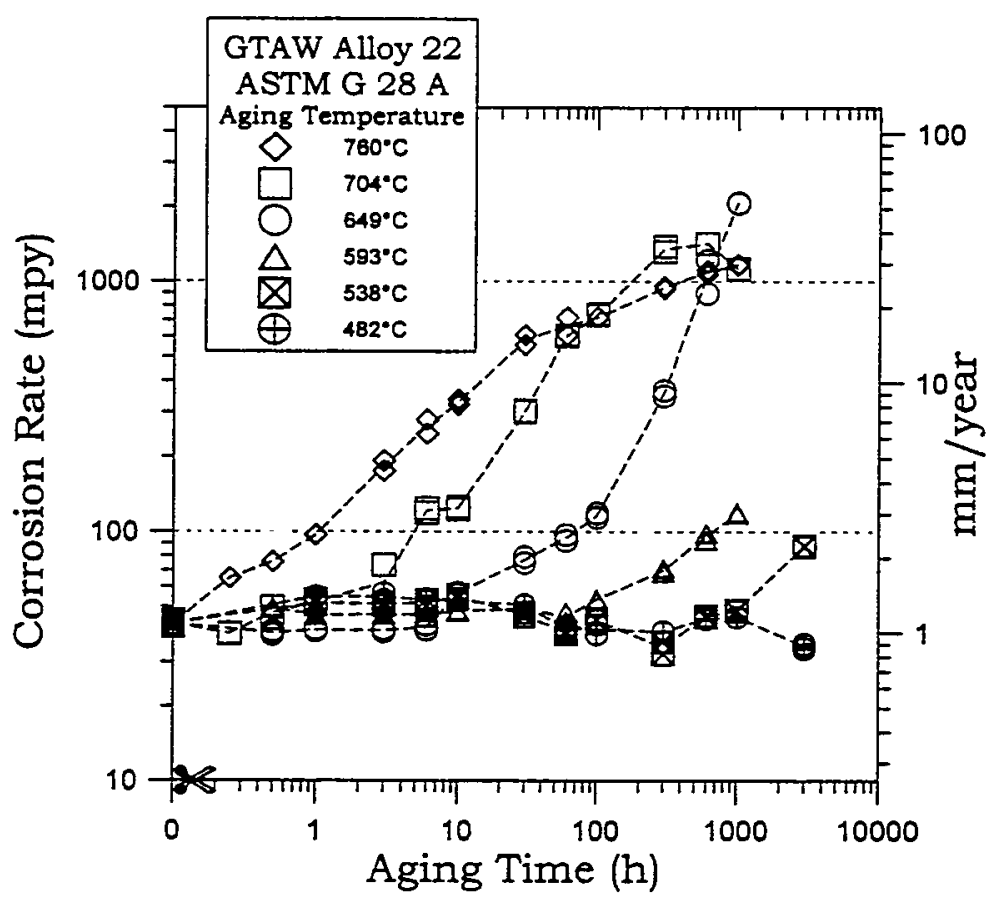

FIGURE 5: Corrosion rate of aged GTAW Alloy 22 in ASTM G 28 A. 


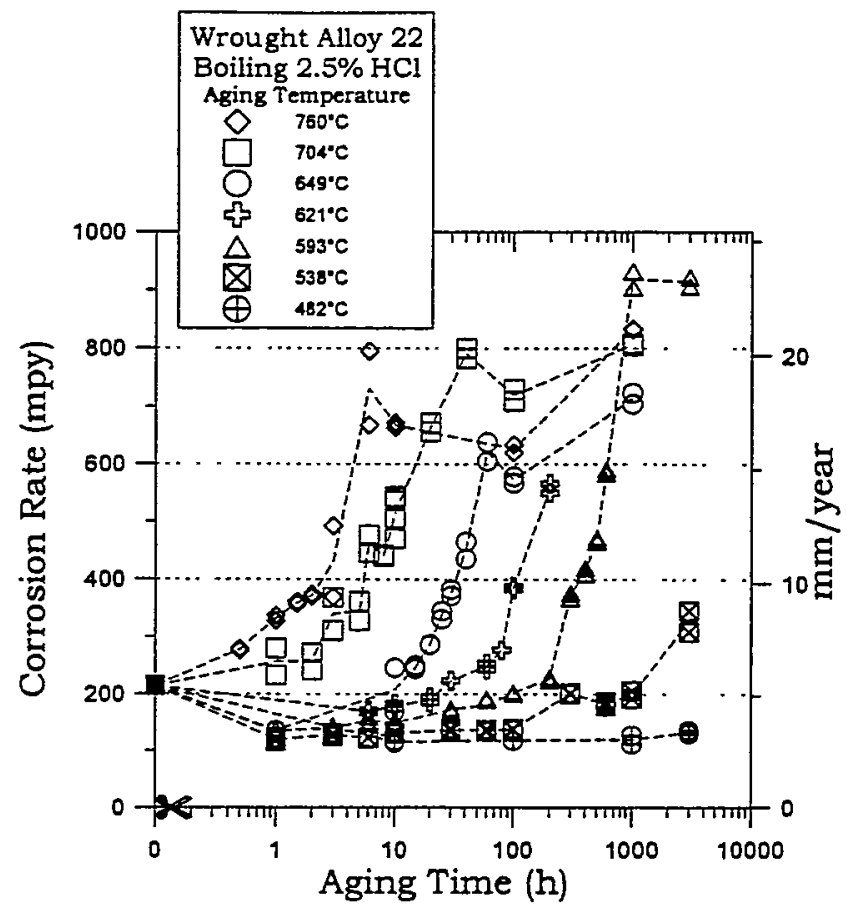

FIGURE 6: Corrosion rate of aged wrought Alloy 22 in boiling $2.5 \% \mathrm{HCl}$.

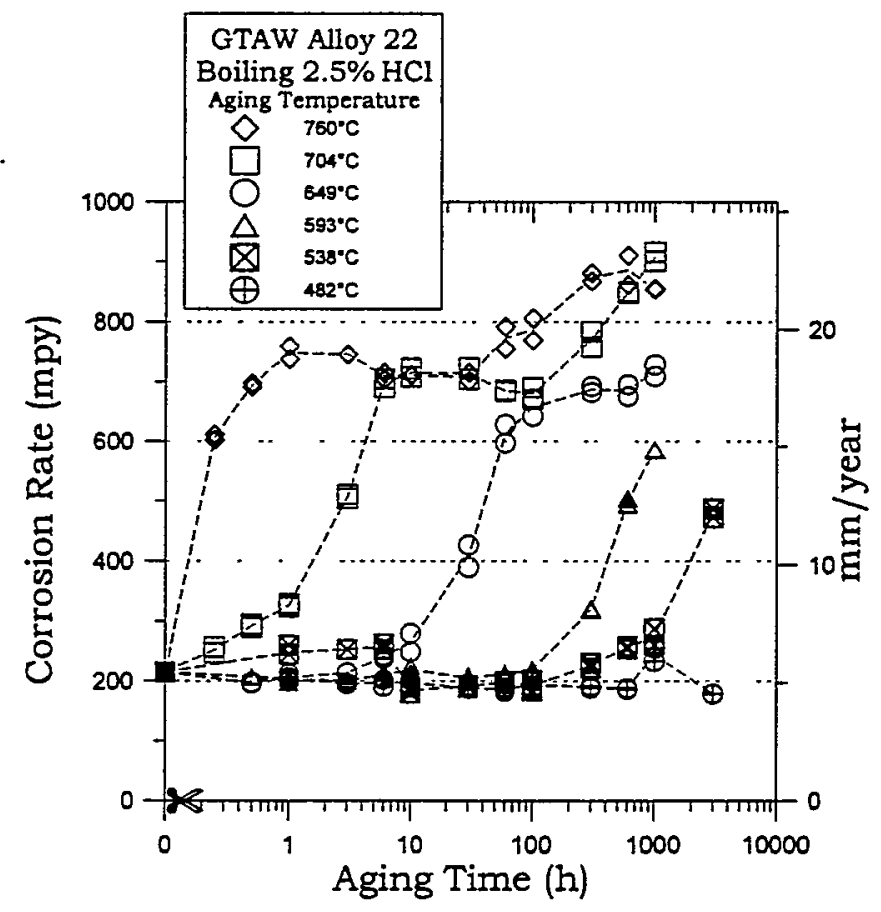

FIGURE 7: Corrosion rate of aged GTAW Alloy 22 in boiling $2.5 \% \mathrm{HCl}$. 


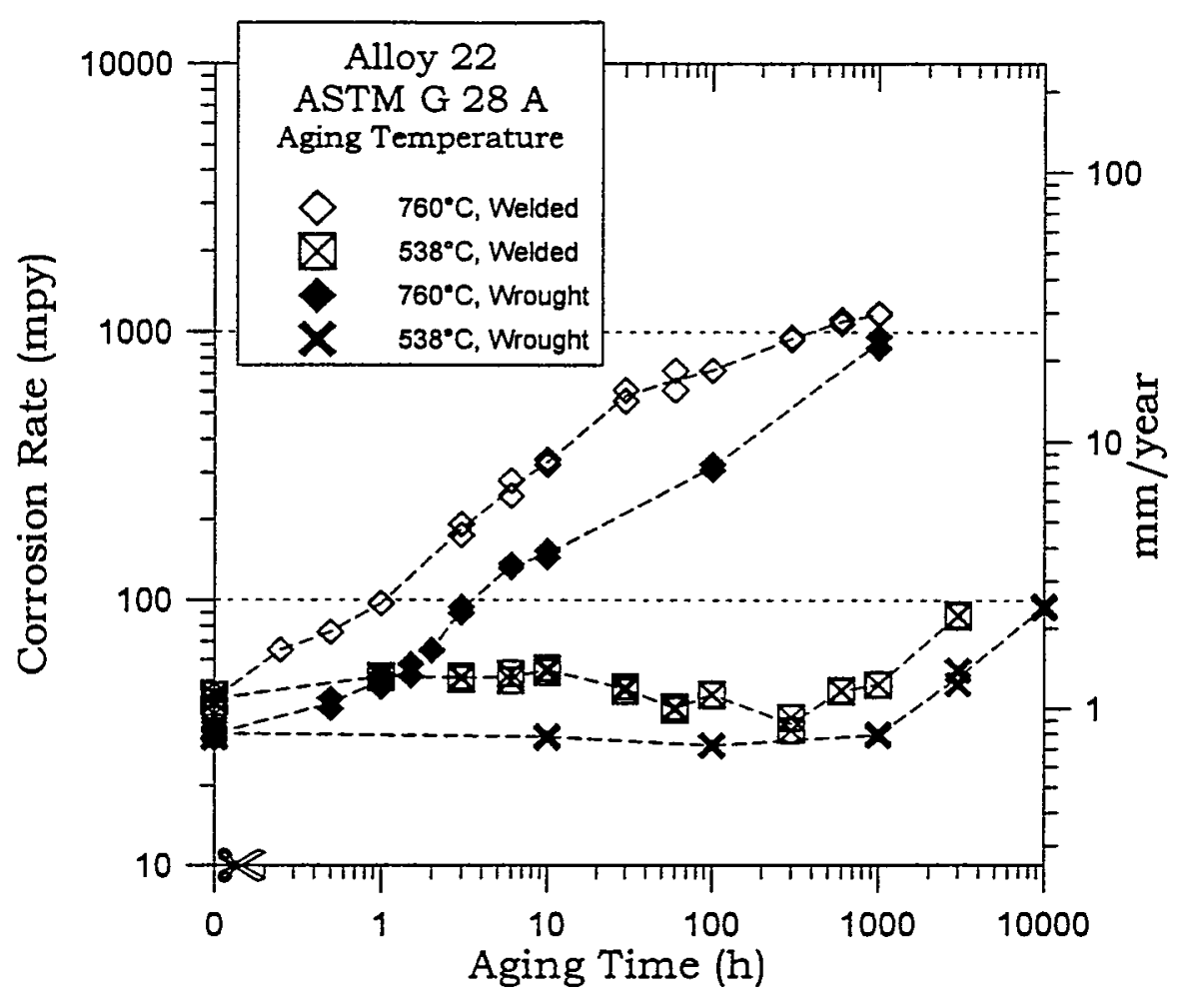

FIGURE 8: Corrosion rate in G 28 A solution for wrought and GTAW Alloy 22.

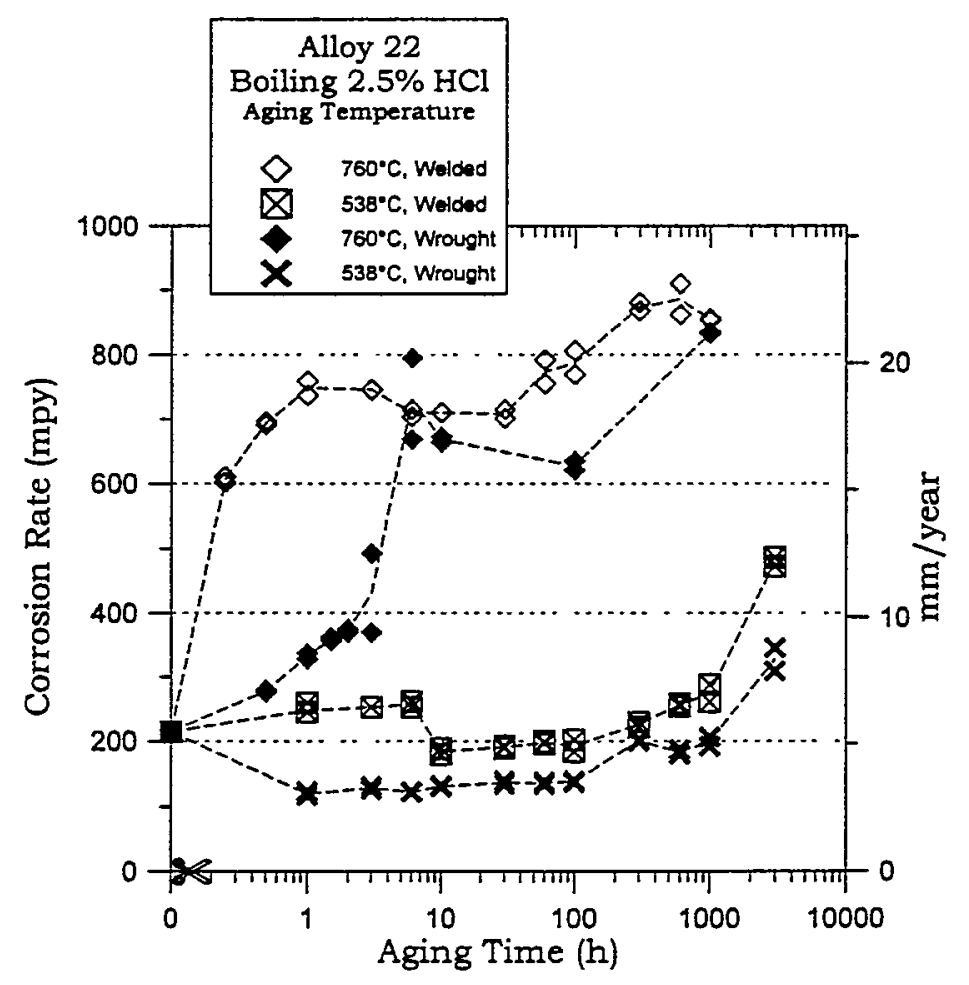

FIGURE 9: Corrosion rate in boiling 2.5\% $\mathrm{HCl}$ solution for wrought and GTAW Alloy 22. 


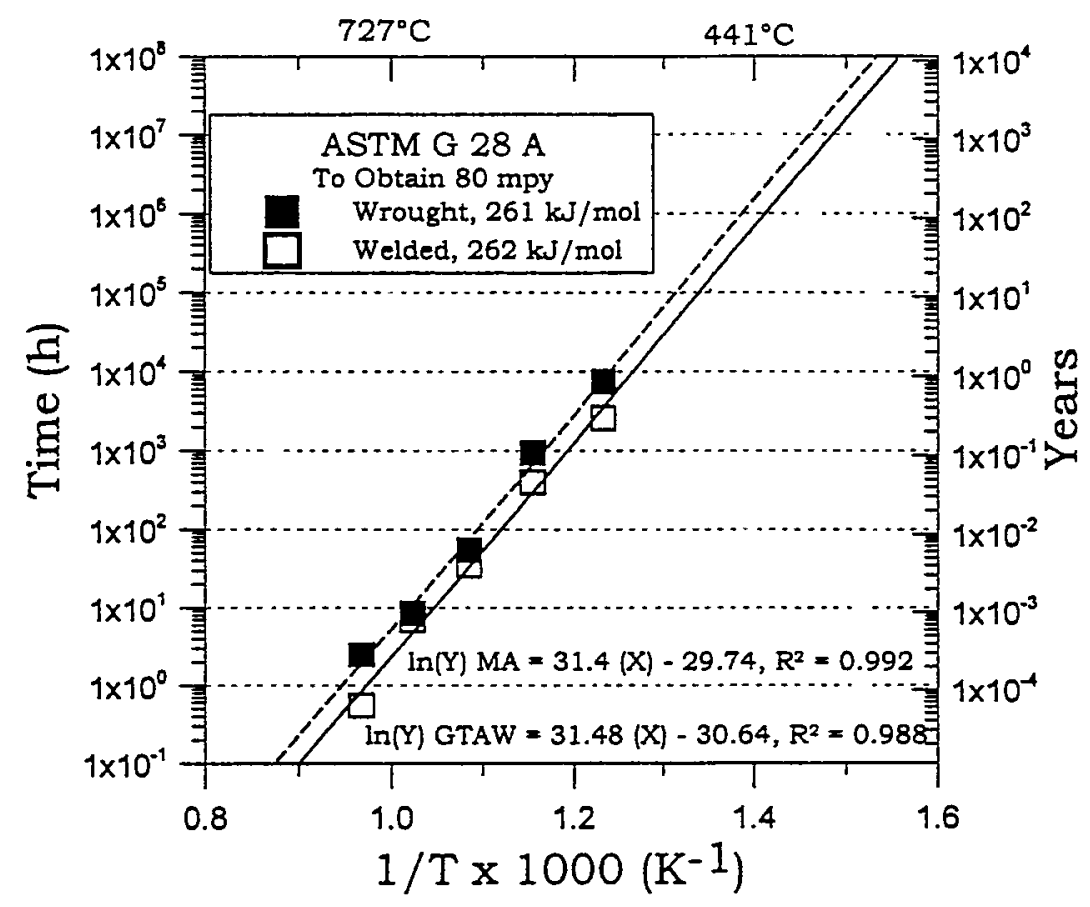

FIGURE 10: Arrhenius extrapolation for the corrosion behavior of wrought and GTAW Alloy 22. 